\title{
Case Report: Cerebral venous thrombosis revealing celiac
}

\section{disease [version 1; peer review: 2 approved with reservations]}

\author{
Romdhane Wiem (D1) Arfa Sondess (iD)1,2, Chelly Jihene1,2, Jomaa Olfa(D1, \\ Hammami Sonia ${ }^{2-4}$, Hmida Karima (DiD) , El Arbi Fatma1,2, Berriche Olfa1-3
}

\author{
${ }^{1}$ Department of Endocrinology and Internal Medicine, Tahar Sfar University Hospital, Mahdia, 5100, Tunisia \\ ${ }^{2}$ Faculty of Medicine, University of Monastir, Monastir, 5000, Tunisia \\ ${ }^{3}$ Biochemistry Laboratory, LR12ES05 LR-NAFS Nutrition-Functional Food and Vascular Health, Faculty of Medicine, University of \\ Monastir, Monastir, 5000, Tunisia \\ ${ }^{4}$ Department of Endocrinology and Internal Medicine, Fattouma Bourguiba University Hospital, Monastir, 5000, Tunisia \\ ${ }^{5}$ Department of Radiology, Tahar Sfar University Hospital, Mahdia, 5100, Tunisia
}

V1 First published: 28 Jul 2021, 10:680

https://doi.org/10.12688/f1000research.54233.1

Latest published: 10 Sep 2021, 10:680

https://doi.org/10.12688/f1000research.54233.2

\section{Abstract}

Celiac disease (CD) is an autoimmune enteropathy resulting from intolerance of an individual genetically predisposed to gluten. It has a large clinical polymorphism ranging from a classic digestive clinical presentation due to the malabsorption syndrome to extra-intestinal symptoms. Among the hematologic abnormalities, venous thromboembolic disease (VTE) has been reported, and they are most often located in the abdomen or lower limbs, but the cerebral localization was exceptionally described. We report a case of CD revealed by cerebral thrombophlebitis.

A 44-year-old patient with no medical history and no drug intake, presented with hemiplegia followed by a status epilepticus in a context of apyrexia, initially hospitalized in intensive care. Magnetic imaging resonance displayed a cerebral venous thrombosis of the sigmoid sinus requiring anticoagulant treatment, then transferred to our department for the etiological investigation. On questioning, the patient reported chronic diarrhea and weight loss with no other associated symptoms. The examination revealed an underweight patient with pale conjunctiva, improvement of her deficit symptoms, and no other abnormalities.

Laboratory tests noted biological signs of malabsorption. The thrombophilia assessment revealed a protein C deficiency with a slight increase in anticardiolipin antibodies and anti-Beta 2 glycoprotein 1 antibodies. Immunological tests noted positives anti-transglutaminase and IgA anti-endomysium antibodies. Duodenal biopsy demonstrated villous atrophy. After ruling out the other causes of VTE, the diagnosis of cerebral venous thrombosis secondary to CD was retained.

Early diagnosis and treatment of CD improves the quality-of-life for patients and may spare them various long-term or even fatal complications.

\section{Open Peer Review}

Approval Status

1

2

version 2

(revision)

10 Sep 2021

version 1

28 Jul 2021

$\begin{array}{cc} & \\ \text { view } & \text { view } \\ ? & ? \\ \text { view } & \text { view }\end{array}$

1. Juha Taavela $(\mathrm{D})$, Tampere University,

Tampere, Finland

Central Finland Central Hospital, Jyväskylä,

Finland

2. Bouomrani Salem, Military Hospital of

Gabes, Gabes, Tunisia

Any reports and responses or comments on the article can be found at the end of the article. 


\section{Keywords}

Celiac disease; venous thromboembolic disease; malabsorption syndrome; Hypercoagulability.

Corresponding author: Romdhane Wiem (wiem.romdhane5@gmail.com)

Author roles: Wiem R: Investigation, Writing - Original Draft Preparation; Sondess A: Supervision; Jihene C: Investigation; Olfa J: Investigation; Sonia H: Writing - Review \& Editing; Karima H: Investigation; Fatma EA: Investigation; Olfa B: Supervision, Validation, Writing - Review \& Editing

Competing interests: No competing interests were disclosed.

Grant information: The author(s) declared that no grants were involved in supporting this work.

Copyright: ( 2021 Wiem R et al. This is an open access article distributed under the terms of the Creative Commons Attribution License, which permits unrestricted use, distribution, and reproduction in any medium, provided the original work is properly cited.

How to cite this article: Wiem R, Sondess A, Jihene $C$ et al. Case Report: Cerebral venous thrombosis revealing celiac disease

[version 1; peer review: 2 approved with reservations] F1000Research 2021, 10:680 https://doi.org/10.12688/f1000research.54233.1

First published: 28 Jul 2021, 10:680 https://doi.org/10.12688/f1000research.54233.1 


\section{Introduction}

Celiac disease (CD) is an autoimmune enteropathy resulting from intolerance of an individual genetically predisposed to gluten. It affects $0.6-1.0 \%$ of the world population. ${ }^{1}$ It has a large clinical polymorphism ranging from a classic digestive clinical presentation due to the malabsorption syndrome; diarrhea and abdominal pain; to extra-intestinal symptoms. ${ }^{2}$ It requires lifelong adherence to a gluten-free diet.

Among the hematologic abnormalities, venous thromboembolic disease (VTE) has been reported in the literature, with a $25 \%$ higher risk in patients with CD compared with the general population. ${ }^{3}$ VTE is most often located in the abdomen or lower limbs, but the cerebral localization has been exceptionally described. ${ }^{4}$

Here, we report a case of CD revealed by cerebral venous thrombosis discovered while exploring a status epilepticus. This presentation has not been reported previously in the literature.

\section{Case report}

A 44-year-old Tunisian female patient, housewife, with no medical history and no drug intake, presented with hemiplegia followed by a status epilepticus in a context of apyrexia, initially hospitalized in intensive care. Neuroimaging displayed a cerebral venous thrombosis of the superior sagittal sinus (Figure 1) requiring anticoagulant treatment (low-molecular -weight -heparin $100 \mathrm{IU} / \mathrm{kg} \times 2 / 24 \mathrm{~h}$ followed by Warfarin for 6 months. After treatment, the patient was transferred to our department of Internal Medicine for the etiological investigation.

On examination, the patient reported chronic diarrhea and weight loss with no other associated symptoms. Physical examination revealed an underweight patient (BMI:16.9) with pale conjunctiva, improvement of hemiparesis, and no other abnormalities. Laboratory tests noted biological signs of malabsorption. [(Hemoglobin: $10 \mathrm{~g} / \mathrm{dl}$ (normal range $>$ $12 \mathrm{~g} / \mathrm{dl}$ ), Albumin: $17.9 \mathrm{~g} / \mathrm{L}$, cholesterol: $2.8 \mathrm{mmol} / \mathrm{l}$ (normal range $<5,1 \mathrm{mmol} / \mathrm{l})$.]

Thrombophilia assessment revealed a protein C deficiency 57\% (normal range: 70-120\%), a slight increase in anticardiolipin antibodies $11 \mathrm{IU} / \mathrm{ml}$ (normal range $<7 \mathrm{UI} / \mathrm{ml}$ ) and anti-Beta 2 glycoprotein 1 antibodies $18 \mathrm{IU} / \mathrm{ml}$ (normal range $<8 \mathrm{IU} / \mathrm{ml}$ ) with normal levels of protein $\mathrm{S}$, antithrombin III and homocysteinemia, and negative factor V Leiden. Immunological tests noted positive anti-transglutaminase $>50 \mathrm{IU} / \mathrm{ml}$ (normal range $<8 \mathrm{U} / \mathrm{ml}$ ) and anti-endomysium antibodies at $0.6 \mathrm{~g} / \mathrm{L}$ (normal range $<0.2 \mathrm{~g} / \mathrm{L}$ ).

From examination and laboratory results, VTE was diagnosed and CD as the cause was suspected. Duodenal biopsy demonstrated villous atrophy, meaning that the diagnosis of CD could be retained after ruling out the other causes of VTE as the neoplastic aetiologies; gynaecologic examination didn't show a lesion, neither chest radiography or colonoscopy.

The outcome of the patient was deemed favorable with anticoagulant therapy (low-molecular weight Heparin followed by Warfarin for 6 months without bleeding complications), combined with a gluten-free diet during the follow-ups over a period of 3-years in our outpatient consultation.

\section{Discussion}

$\mathrm{CD}$ is defined as a chronic immune-mediated small intestinal enteropathy caused by gluten intolerance in genetically predisposed individuals. ${ }^{5}$ The activation of both the innate and adaptive response of the immune system, following the
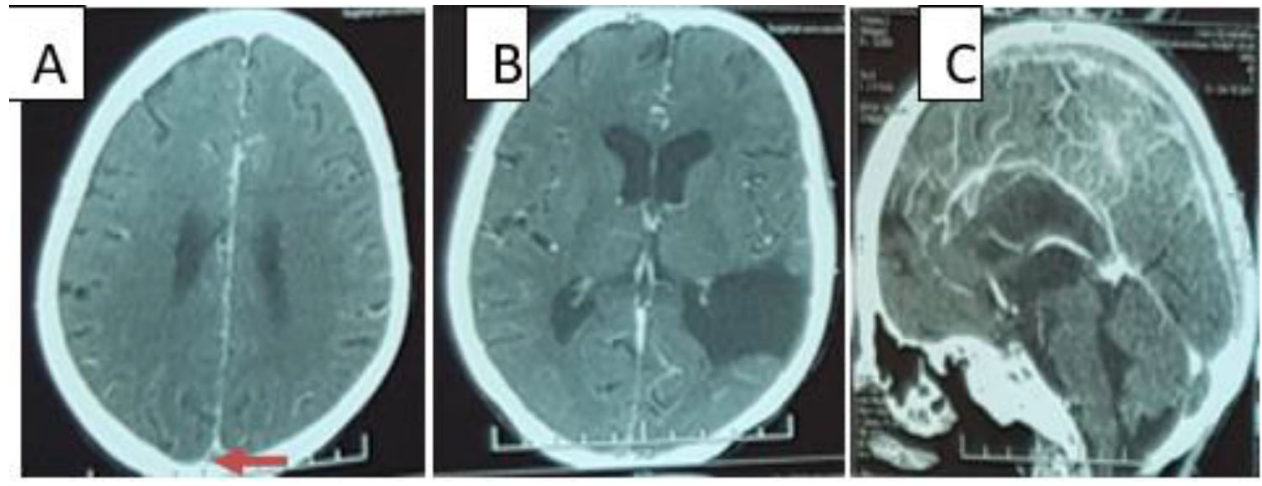

Figure 1. Cerebral CT scan (A, B: axial plane, C: Sagittal plane) showing a venous thrombosis of superior sagittal sinus $(A, C)$ and a left temporoparietal porencephalic cyst (B). 
ingestions of gluten leads to damage to the proximal mucosa of the small intestine, resulting in the malabsorption of nutrients and the appearance of extra-intestinal manifestations.

$\mathrm{CD}$ is a systemic disorder, with different forms of clinical manifestations, from a classic digestive clinical presentation to extra-intestinal symptoms. The intestinal form of CD is more commonly found in the pediatric population ${ }^{6}$ and rarely in adults. It includes diarrhea, which is a common presenting sign, in addition to malabsorption symptoms.

Nevertheless, extra-intestinal manifestations are being increasingly recognized, most likely due to better awareness of atypical presentations. They can include chronic fatigue, anemia, osteoporosis, recurrent aphthous stomatitis, elevated liver enzymes, joint or muscle pain, epilepsy, peripheral neuropathy, and infertility ${ }^{7}$ Therefore, it is reported that extraintestinal manifestations may appear before the diagnosis of $\mathrm{CD}$, as shown in our case.

It has been recognized that chronic inflammation is also an independent risk factor for VTE as the consequence of inflammatory cytokines and oxidative stress on the coagulation cascade is demonstrated.

Our patient presented a deficiency of protein $\mathrm{C}$; which has been reported in previous studies related to $\mathrm{CD}$, results in the over activity of coagulation factors $\mathrm{V}$ and VIII thus increasing the risk for thrombotic events. ${ }^{9}$ We noted also a slight increase in anticardiolipin antibodies and anti-Beta 2 glycoprotein 1 antibodies, as shown in several studies where a higher prevalence of autoantibodies among patients with $\mathrm{CD}$, including anti-phospholipid antibodies (see review of studies $\mathrm{in}^{9}$ ). It is possible that these anti-phospholipid antibodies might also contribute to hypercoagulability.

A thrombosis assessment should be considered in patients with $\mathrm{CD}$ as the risk factors for thrombosis can be acquired in $\mathrm{CD}$ by a vitamin deficiency or antiphospholipid antibodies. These factors must be investigated, corrected, and even thromboembolic prophylaxis should be initiated.

VTE as a presentation of CD is unusual and rarely reported, especially since this thrombosis is located in the cerebrum. The seriousness of these manifestations show that malabsorption syndrome should be systematically investigated to explore any symptoms due to systemic complications of malabsorption, for early diagnosis and better prognosis. Furthermore, a long diagnostic delay may increase the risk of poor clinical response. ${ }^{10}$

In fact, other central nervous system manifestations were reported more associated to CD than cerebral thrombosis, including cerebellar ataxia, peripheral neuropathy, seizures, headache, cognitive impairment, and psychiatric symptoms. ${ }^{11}$

Early diagnosis and treatment of CD improves the quality-of-life for patients and may spare them various long-term or even fatal complications like thromboembolic diseases.

\section{Data availability}

All data underlying the results are available as part of the article and no additional source data are required.

\section{Consent}

Written informed consent for publication of the clinical details and associated images was obtained from the patient.

\section{References}

1. Biagi F, Klersy $C$, Balduzzi D, et al.: Are we not over-estimating the prevalence of celiac disease in the general population? Ann Med. 2010; 42: 557-561.

PubMed Abstract | Publisher Full Text

2. Halfdanarson TR, Litzow MR, Murray JA: Hematologic manifestations of celiac disease. Blood. 2007; 109(2): 412-421.

PubMed Abstract | Publisher Full Text | Free Full Text

3. Ungprasert $P$, Wijarnpreecha $K$, Tanratana $P$ : Risk of venous thromboembolism in patients with celiac disease: a systematic review and meta-analysis. J Gastroenterol Hepatol. 2016; 31: $1240-1245$.

PubMed Abstract | Publisher Full Text
4. Bouziane M, Arous S, Habbal R: Cerebral venous thrombosis as a rare thromboembolic complication of celiac disease: a case report. Eur Heart J Case Rep. 2020; 4(5): 1-5.

PubMed Abstract | Publisher Full Text | Free Full Text

5. Husby S, Koletzko S, Korponay-Szabó IR, et al.: European Society for Pediatric Gastroenterology, Hepatology, and Nutrition guidelines for the diagnosis of coeliac disease. J Pediatr Gastroenterol Nutr. 2012 Jan; 54(1): 136-160. PubMed Abstract | Publisher Full Text

6. Vivas S, Ruiz de Morales JM, Fernandez M, et al.: Age-related clinical, serological, and histopathological features of celiac disease. Am J Gastroenterol. 2008 Sep; 103(9): 
2360-2365; quiz 2366.80

PubMed Abstract | Publisher Full Text

7. Kayar Y, Dertli R, Sürmeli N, et al.: Extraintestinal

Manifestations Associated with Celiac Disease. East J Med. 2019;

24(4): 478-483.

PubMed Abstract | Publisher Full Text

8. Samad F, Ruf W: Inflammation, obesity, and thrombosis. Blood 2013; 122: 3415-3422.

PubMed Abstract | Publisher Full Text | Free Full Text

9. Previtali E, Bucciarelli P, Passamonti SM, et al.: Risk factors for venous and arterial thrombosis. Blood Transfus. 2011; 9(2):
120-138.

PubMed Abstract | Publisher Full Text | Free Full Text

10. Fuchs V, Kurppa K, Huhtala $\mathrm{H}$, et al.: Delayed celiac disease diagnosis predisposes to reduced quality of life and incremental use of health care services and medicines: A prospective nationwide study. United European Gastroenterol J. 2018 May; 6(4): 567-575.

PubMed Abstract | Publisher Full Text | Free Full Text

11. Pennisi $M$, Bramanti $A$, Cantone $M$, et al.: Neurophysiology of the "Celiac Brain": Disentangling Gut-Brain Connections. Front Neurosci. 2017; 11: 498.

PubMed Abstract | Publisher Full Text | Free Full Text 


\section{Open Peer Review}

\section{Current Peer Review Status: ? ?}

\section{Version 1}

Reviewer Report 27 August 2021

https://doi.org/10.5256/f1000research.57696.r91588

(C) 2021 Salem B. This is an open access peer review report distributed under the terms of the Creative Commons Attribution License, which permits unrestricted use, distribution, and reproduction in any medium, provided the original work is properly cited.

\section{Bouomrani Salem}

Department of Internal Medicine, Military Hospital of Gabes, Gabes, Tunisia

The authors present an original case report of cerebral venous thrombosis occurring in a patient with celiac disease and discuss the causal link between these two pathologies. Indeed, thromboembolic complications are part of the possible extra-intestinal manifestations of this disease with several cases and different locations reported.

The authors insist on the fact that the revealing character, as well as the status epilepticus, is the element which makes the originality of their observation.

Some modifications are necessary before the indexing of this manuscript:

1. Keywords: add "cerebral venous thrombosis" to the list of keywords

2. Introduction: remove the last sentence "This presentation has not been reported previously in the literature." and replace it with "this clinical situation remains exceptional and unusual during CD". Indeed, several cases of cerebral venous thrombosis as the first manifestation of $C D$ have been reported in the literature, some of which are associated with convulsive seizures or epilepsy. Seizures are nonspecific and can simply be a consequence of cerebral thrombosis. This possibility must be mentioned.

3. Case report: the assessment of thrombophilia is incomplete. The other tests should be noted (if they were performed): prothrombin G20210A mutation (Factor II Mutation)? Tumor markers? Anti nuclear antibodies? Lupus anticoagulant?

\section{Discussion:}

The causal link between CVT and CD must be well discussed and the possible mechanisms of hypercoagulability during this disease well explained i.e. deficiencies in B12, folate and vitamin $\mathrm{K}$, persistent chronic inflammation, hyperhomocysteinemia, the presence of antiphospholipids antibodies, fibrinolysis abnormalities, endothelial dysfunction, thrombocytosis, etc. 
The presence of antiphospholipid antibodies in this patient should also be discussed: simple positivity of these autoantibodies already reported during $C D$, or an authentic antiphospholipid syndrome associated with CD (venous thrombosis + positive anticardiolipin antibodies and anti-Beta 2 glycoprotein 1 antibodies). The association of these two autoimmune diseases remains a possible eventuality! ${ }^{1}$ Is the control of these autoantibodies carried out at 12 weeks?

The possible origin of protein C deficiency must also be discussed: a real thrombophilia? protein loss through diarrhea? or the received anticoagulant treatment (Warfarin)?

5. Bibliography: the list of bibliographic references is not well selected. Indeed, to support the discussion, the cases reporting CVT and CD, in particular the inaugural forms and associated with epilepsy, may be cited and used in the discussion: [refs 2-6]

Likewise, the very latest update on thromboembolic and cardiovascular complications associated with CD should be cited in the list of bibliographic references and used to discuss the different possible mechanisms of thrombogenesis during this disease ${ }^{7}$.

\section{References}

1. Jorge O, Jorge A, Camus G: [Celiac disease associated with antiphospholipid syndrome].Rev Esp Enferm Dig. 2008; 100 (2): 102-3 PubMed Abstract | Publisher Full Text

2. Bahloul M, Chaari A, Khlaf-Bouaziz N, Kallel H, et al.: [Celiac disease, cerebral venous thrombosis and protein S deficiency, a fortuitous association?].J Mal Vasc. 2005; 30 (4 Pt 1): 228-30 PubMed Abstract | Publisher Full Text

3. Alhosain D, Kouba L: Concurrent cerebral arterial and venous sinus thrombosis revealing celiac disease- a case report and literature review.BMC Gastroenterol. 2020; 20 (1): 327 PubMed Abstract | Publisher Full Text

4. Beyrouti $\mathrm{R}$, Mansour $\mathrm{M}$, Kacem $\mathrm{A}$, Derbali $\mathrm{H}$, et al.: Recurrent cerebral venous thrombosis revealing celiac disease: an exceptional case report.Acta Neurol Belg. 117 (1): 341-343 PubMed Abstract | Publisher Full Text

5. Boucelma M, Saadi M, Boukrara H, Bensalah D, et al.: [Association of celiac disease and cerebral venous thrombosis: report of two cases].J Mal Vasc. 2013; 38 (1): 47-51 PubMed Abstract I Publisher Full Text

6. Doğan M, Peker E, Akbayram S, Bektas MS, et al.: Cerebral venous sinus thrombosis in 2 children with celiac disease.Clin Appl Thromb Hemost. 2011; 17 (5): 466-9 PubMed Abstract I Publisher Full Text

7. Fousekis FS, Beka ET, Mitselos IV, Milionis H, et al.: Thromboembolic complications and cardiovascular events associated with celiac disease.Ir J Med Sci. 2021; 190 (1): 133-141 PubMed Abstract | Publisher Full Text

Is the background of the case's history and progression described in sufficient detail? No

Are enough details provided of any physical examination and diagnostic tests, treatment given and outcomes? 
No

Is sufficient discussion included of the importance of the findings and their relevance to future understanding of disease processes, diagnosis or treatment?

Partly

Is the case presented with sufficient detail to be useful for other practitioners?

Partly

Competing Interests: No competing interests were disclosed.

Reviewer Expertise: Autoimmune diseases, Internal Medicine, Thrombophilias

I confirm that I have read this submission and believe that I have an appropriate level of expertise to confirm that it is of an acceptable scientific standard, however I have significant reservations, as outlined above.

Reviewer Report 23 August 2021

https://doi.org/10.5256/f1000research.57696.r92258

(C) 2021 Taavela J. This is an open access peer review report distributed under the terms of the Creative Commons Attribution License, which permits unrestricted use, distribution, and reproduction in any medium, provided the original work is properly cited.

\section{Juha Taavela}

${ }^{1}$ Celiac Disease Research Center, Faculty of Medicine and Health Technology, Tampere University, Tampere, Finland

2 Central Finland Central Hospital, Jyväskylä, Finland

The authors have found celiac disease in a patient with venous thromboembolism. I especially like the conclusion that early diagnosis of CD is needed which is an important topic in CD (Popp et al., 2019). The case report is interesting, however, I have some comments:

The link between celiac disease and VTE is unknown. The authors suggest in the discussion that a thrombosis assessment should be considered in CD patients. Such a conclusion cannot be drawn from a couple of case reports. And the suggestion of thromboembolic prophylaxis is also not supported by such small data. I believe the situation is similar as in IBD, in which the acute phase causes a risk for VTE (Grainge et al, 2010). However, celiac disease is a much easier disease to treat than some IBDs, and such acute situations in the ER are not seen in CD. This must be changed in the discussion.

Another thing to discuss is that is the cause of protein C deficiency, coagulation factors and anti-phospholipid antibodies CD or just the fulminant diarrhea and nutrition deficiency?

As a minor remark the article should also mention that a significant proportion of celiacs are nowadays found while screening in-at risk groups such as Graves disease, type 1 
diabetes etc (2). And these patients are without any symptoms but they benefit from treatment (Kurppa et al., 2014).

\section{References}

1. Grainge $M$, West J, Card T: Venous thromboembolism during active disease and remission in inflammatory bowel disease: a cohort study. The Lancet. 2010; 375 (9715): 657-663 Publisher Full Text

2. Popp A, Kivelä L, Fuchs V, Kurppa K: Diagnosing Celiac Disease: Towards Wide-Scale Screening and Serology-Based Criteria?. Gastroenterol Res Pract. 2019; 2019: 2916024 PubMed Abstract | Publisher Full Text

3. Kurppa K, Paavola A, Collin P, Sievänen $\mathrm{H}$, et al.: Benefits of a gluten-free diet for asymptomatic patients with serologic markers of celiac disease.Gastroenterology. 2014; 147 (3): 610-617.e1 PubMed Abstract | Publisher Full Text

Is the background of the case's history and progression described in sufficient detail? Yes

Are enough details provided of any physical examination and diagnostic tests, treatment given and outcomes?

Yes

Is sufficient discussion included of the importance of the findings and their relevance to future understanding of disease processes, diagnosis or treatment?

Partly

Is the case presented with sufficient detail to be useful for other practitioners? Yes

Competing Interests: No competing interests were disclosed.

Reviewer Expertise: Celiac disease, gluten sensitivity

I confirm that I have read this submission and believe that I have an appropriate level of expertise to confirm that it is of an acceptable scientific standard, however I have significant reservations, as outlined above. 
The benefits of publishing with F1000Research:

- Your article is published within days, with no editorial bias

- You can publish traditional articles, null/negative results, case reports, data notes and more

- The peer review process is transparent and collaborative

- Your article is indexed in PubMed after passing peer review

- Dedicated customer support at every stage

For pre-submission enquiries, contact research@f1000.com 